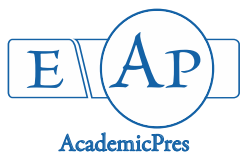

Inyang P et al. (2021)

Notulae Scientia Biologicae 13(1):10691

DOI: $10.15835 / \mathrm{nsb} 13110691$

Research Article

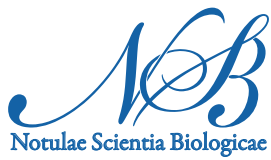

\title{
Environmental impact and genetic expressions of new drought-tolerant maize genotypes in derived savannah agro-ecology
}

\author{
Paul INYANG ${ }^{1,2}$, Chikezie O. ENE ${ }^{2,3 *}$, Ankrumah EMMANUEL ${ }^{2}$, \\ Uchechukwu P. CHUKWUDI ${ }^{4,5}$, Ugochukwu N. IKEOGU 6 \\ ${ }^{1}$ Federal University of Technology, Department of Crop Science and Technology, Owerri, Nigeria; paulinyang@yahoo.com \\ ${ }^{2}$ Alex Ekwueme-Federal University Ndufu-Alike, Department of Agriculture, Abakaliki, Nigeria; \\ enechike17@gmail.com; (*correspondingauthor)ankrumahemmanuel@gmail.com \\ ${ }^{3}$ Jimma University, Department of Horticulture and Plant Science, Jimma, Ethiopia \\ ${ }^{4}$ University of Nigeria, Department of Crop Science, Nsukka, Enugu, Nigeria; upchukwudi@gmail.com \\ ${ }^{5}$ North-West University, Department of Crop Science, Mmabatho, South Africa \\ ${ }^{6}$ Cornell University, Section of Plant Breeding and Genetics, Ithaca, New York, USA; uni3@cornell.edu
}

\begin{abstract}
Reduced water resources in sub-Saharan Africa will not only pose threat to the livelihood of poor resource farmers, but also food security in the region. Drought tolerant (DT) maize varieties hold promise to reducing poor resourced farmers' vulnerability and improve food security in sub-Saharan Africa. Ten maize genotypes obtained from the International Institute of Tropical Agriculture (IITA), were evaluated in 2015 and 2016 using a randomized complete block design experiment with three replications to estimate their genetic variability and predict their genetic advances in the derived savannah agro-ecology. Growth, phenological and yield data were collected from 10 middle row plants. Genetic advance, genotypic, phenotypic and environmental coefficients of variations and their variances were estimated. Principal component and hierarchical cluster analyses were also performed. The dendrogram showed that at $80 \%$ dissimilarity point, the genotypes were grouped into clusters A, B and C in both years. The first two principal components explained $91.8 \%$ and $93.3 \%$ of the total variation in 2015 and 2016, respectively. Number of grains cob- ${ }^{1}$, plant height and number of days to physiological maturity were consistent in explaining the variations observed in the maize population. Heritability estimates in broad sense ranged from $1.35 \%$ for number of leaves to $87.43 \%$ for grain yield per hectare. The genetic parameters studied showed significant variations among the growth, phenological and yield data collected that warrants selection and maize improvement program using the DT maize inbred lines in derived savannah agro-ecology.
\end{abstract}

Keywords: climate change; genetic improvement; heritability; sub-Saharan Africa; water stress; Zea mays L.

\section{Introduction}

Maize (Zea mays L.) is the third most utilized cereal crop after wheat and rice in Nigeria (OECD/FAO, 2016) and globally based on harvested area (Ramirez-Cabral et al., 2017). In sub-Saharan Africa (SSA), maize

Received: 28 Mar 2020. Received in revised form: 29 Dec 2020. Accepted: 12 Jan 2021. Published online: 19 Jan 2021.

From Volume 13, Issue 1, 2021, Notulae Scientia Biologicae journal will use article numbers in place of the traditional method of continuous pagination through the volume. 
is the single most important staple crop for about 950 million people (OECD/FAO, 2016). Its consumption is projected to increase by $50 \%$ in the developing world by 2050 (Rosegrant and Msangi, 2011), while its yield is expected to decrease due to negative impact of climate change (Ramirez-Cabral et al., 2017). The reduction in maize yield will be exacerbated by loss of land used in maize cultivation to other crops (NEPAD, 2014).

Strong growth in SSA agricultural output has accrued predominantly from area expansion as opposed to increase in yield per unit area (NEPAD, 2014) with rain-fed agriculture accounting for more than $95 \%$ of the farmed lands (IWMI, 2019). These farmlands are cultivated by poor resource farmers, who lack capacity to adapt to climate change. Hence, the present change in climate evident in reduced water resources in SSA will not only pose threat to the livelihood of these farmers, but also food security in the region. The African continent is facing one of its driest periods in the past three decades (Brandt et al., 2018). Drought has been considered the most important climate factor affecting crop production. It causes decline in yield which affects farmer seed saving, resulting in reduced seed availability and affordability (Kansiime and Mastenbroek 2016).

In response to the water scarcity challenge, the 'Drought Tolerant Maize for Africa' (DTMA) project was launched by CIMMYT, IITA (CIMMYT, 2015; Fisher et al., 2015), with Drought Tolerant (DT) maize varieties released in SSA. DT maize varieties hold promise to reduce poor resourced farmers' vulnerability and improve food security in SSA. However, farmer uptake of DT maize varies from $9 \%$ in Zimbabwe to $61 \%$ in Malawi, with the major barriers to adoption been unavailability of improved seed, inadequate information, lack of resources, high seed price and perceived attributes of different varieties (Fisher et al., 2015). In Nigeria, DT maize is not common among farmers particularly in the derived savannah agro-ecology probably due to exclusion of the zone during the evaluation of the varieties (CIMMYT, 2015). Participatory breeding is a veritable option used in closing variety adoption gap and may ensure affordability and accessibility of seeds with increased knowledge of the new varieties. In addition to drought tolerance, the DT varieties have other attractive traits, such as resistance to major diseases, high protein content as well as beta-carotene in some, low soil nitrogen tolerant, and Striga resistant (CIMMYT, 2015). Thus, they can serve as good gene donors in maize improvement programme.

Understanding the genetic variability in maize is necessary for a successful adoption and crop improvement programme. Estimating variability in yield and yield traits is vital in determining the environmental influence (Ullah et al., 2012; Ene et al., 2016). Concentrating solely on yield increase can be misinforming as several genetic and non-genetic factors as well as biotic and abiotic agents, interplay to determine crop yield. Selecting yield related traits with low environmental influence increases the chances of selecting genotypes with high yield potentials (Uba et al., 2018).

We hypothesize that the genetic potentials of different DT maize varieties will vary under the derived savannah agro-ecological condition. Hence, the objective of this study was to study the genetic variability and estimate environmental influence on ten maize genotypes which included: eight DT, one commercial hybrid and a landrace in the derived savannah agro-ecology.

\section{Materials and Methods}

\section{Description of experimental site}

The field trials were conducted in the Department of Crop Science and Technology, Research Farm, Faculty of Agriculture, Federal University of Technology, Owerri, Nigeria in 2015 and 2016 rain-fed cropping seasons (April to July). The Research Farm $\left(07^{\circ} 02^{\prime} \mathrm{E}, 05^{\circ} 27^{\prime} \mathrm{N} ; 91 \mathrm{~m}\right.$ asl) is characterized by mean annual rainfall of $\approx 2300 \mathrm{~mm}-2700 \mathrm{~mm}$, mean annual temperature of $\approx 18^{\circ} \mathrm{C}$ to $33^{\circ} \mathrm{C}$ and relative humidity of $\approx 72$ to $86 \%$. Owerri lies within the derived savannah agro-ecology of Nigeria.

Soil samples from the experimental site were analysed and classified as ultisol according to the soil taxonomy of the USDA (Soil Survey Staff, 2003). The textural class is loamy sand (sand 84.1\%, silt 5.1\% and clay $10.8 \%)$ that contains low organic carbon $(\approx 1.6 \%)$, and low contents of nitrogen $(0.1 \%)$, phosphorous 
$\left(17.8 \mathrm{mgkg}^{-1}\right)$, basic cations (potassium 0.02, magnesium 1.2, calcium 1.6) in Cmolkg ${ }^{-1}$ with $\mathrm{pH}$ of 5 and 3.8 in $\mathrm{H}_{2} \mathrm{O}$ and $\mathrm{NaCl}$, respectively.

The monthly rainfall distribution, temperature and relative humidity during the field trial periods are displayed in Figure 1. The information was provided by the meteorological unit of the University.

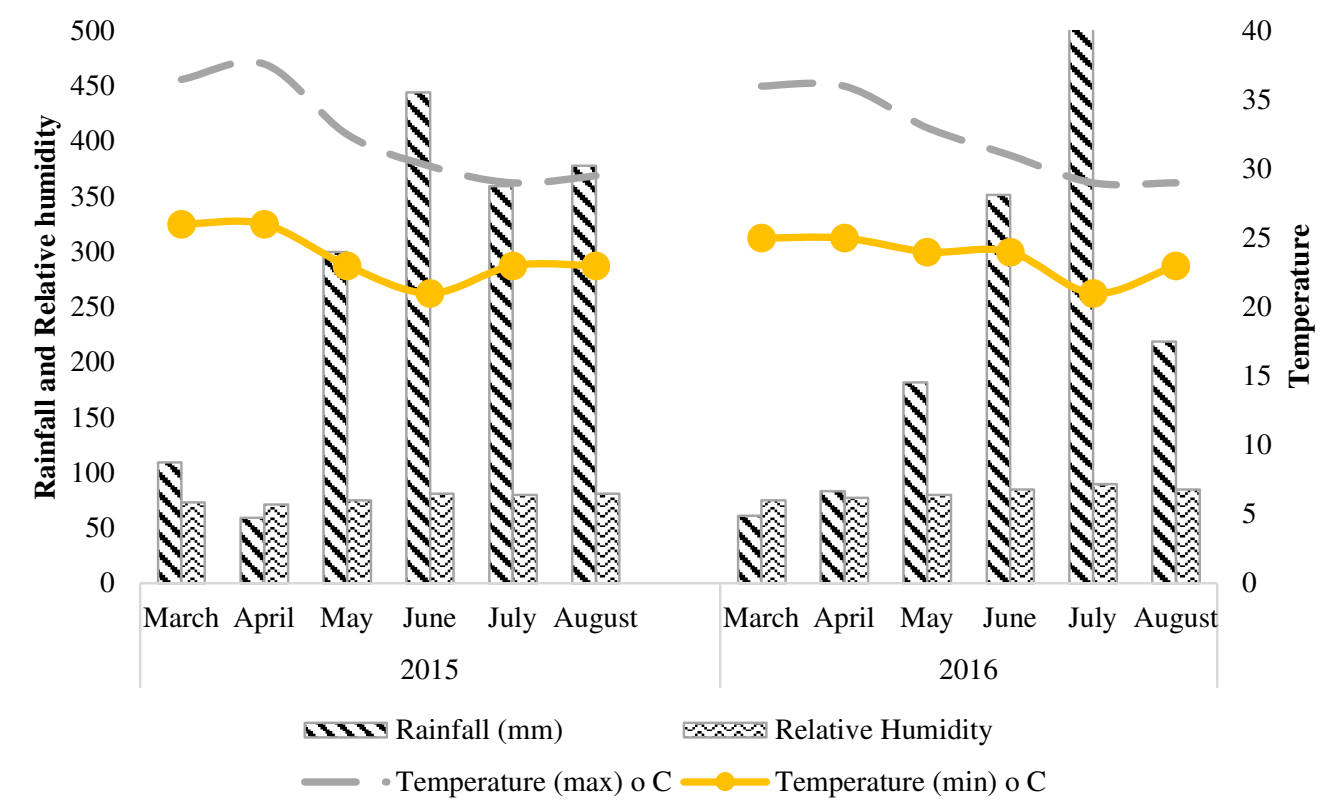

Figure 1. Mean monthly rainfall, temperature, and relative humidity during the experiment interval Source: Meteorological Station, Department of Crop Science and Technology, Federal University of Technology, Owerri

\section{Biological material}

Ten maize genotypes consisting of eight drought tolerant obtained from the International Institute of Tropical Agriculture (IITA) '2008DTMA-YSTR', 'EVDT-Y2000 STRCO', 'TZE COMP.3C2DT', 'IWDC2 SYN- F2', 'IWDC3 SYN/DTSYN-1-W', 'DT-SR-WCQ', 'DT-SYN-7-WF2' and 'DT-SYN-11YF2'; a commercial hybrid 'Oba Super2' obtained from the seed market and a landrace 'Oka Awaka' sourced from a local farmer were evaluated. The genotypes differ in their maturity periods and colour of the grains.

The maize genotypes are described in Table 1.

Table 1. Maize genotypes used within the experiment and their characteristics

\begin{tabular}{|c|c|c|c|c|}
\hline S/N & Maize genotypes & Grain colour & Duration & Remark \\
\hline 1 & '2008DTMA-YSTR' & Yellow & 90days & Early \\
\hline 2 & 'EVDT-Y2000 STRCO' & Yellow & 90days & Early \\
\hline 3 & 'TZE COMP.3C2DT' & White & 90days & Early \\
\hline 4 & 'IWDC2 SYN- F2' & White & 110 days & Intermediate \\
\hline 5 & 'IWDC3 SYN/ DTSYN-1-W' & White & 110 days & Intermediate \\
\hline 6 & 'DT-SR-WCQ' & White & $110-115$ days & Late \\
\hline 7 & 'DT-SYN-7-WF2' & White & $110-115$ days & Late \\
\hline 8 & 'DT-SYN-11-YF2' & Yellow & $110-115$ days & Late \\
\hline 9 & 'Oba Super 2' & Yellow & $110-115$ days & Late \\
\hline 10 & 'Oka Awaka' & Yellow & - & Late \\
\hline
\end{tabular}

Source: International Institute of Tropical Agriculture (IITA), Ibadan, Nigeria 


\section{Experimental layout and cultural practices}

The experimental design used was randomized complete block design with three replications. Land area measuring $558 \mathrm{~m}^{2}(12 \mathrm{mx} 46.5 \mathrm{~m})$ was mechanically ploughed, harrowed and ridged. The prepared land was divided into three blocks ( $3 \mathrm{mx} 46.5 \mathrm{~m}$ each) representing the replications. Each replication contained ten plots representing each genotype. Each plot measured $3 \mathrm{~m} \times 3.75 \mathrm{~m}$ with a plant spacing of $0.75 \mathrm{~m} \times 0.25 \mathrm{~m}$ containing 60 plants per plot and $\approx 53,333$ plants per hectare. A pathway of $1 \mathrm{~m}$ was maintained within and between blocks.

Poultry manure was applied to the plots at 8 tha ${ }^{-1} 2$ weeks before planting and was supplemented with inorganic fertilizer NPK 20:10:10 at a rate of $600 \mathrm{kgha}^{-1}$ (split application) by the $2^{\text {nd }}$ and $5^{\text {th }}$ weeks after emergence. The plots were manually kept weed free.

\section{Data collection}

Data were collected from the 10 middle row plants in each plot. At 8 weeks after planting (WAP), plant heights $(\mathrm{cm})$ were measured with a meter rule from the soil level to the tip of the plant and number of leaves was counted. Phenological data were monitored for number of days to $50 \%$ tassel and silk appearances. Tasselsilk interval was calculated by subtracting the number of days to tasselling from the number of days to silking. Number of days to physiological maturity was monitored and grain filling period determined. After harvest, cobs from each plot were weighed to obtain grain yield. Ten cobs were randomly selected from each plot to determine the average number of grains $\mathrm{cob}^{-1}$. Then, 100 seeds from the selected cobs were weighed to determined 100-seed weight (gram). Another randomly selected ten cobs per plot, as well as entire leaves from ten plants per plot were oven dried at $70{ }^{\circ} \mathrm{C}$ to constant weight in order to obtain the average cob dry weight (gram) and leaf dry matter, respectively.

\section{Statistical analysis}

The data collected were subjected to analysis of variance (ANOVA) using GenStat Release 10.3 Discovery Edition (PC/Windows; VSN International, Hemel Hempstead, Hertfordshire, UK) to obtain the ANOVA Table and means needed for the genetic calculation. Principal component and hierarchical cluster analyses were also carried out with the GenStat software to show the discriminating traits and level of relatedness among the genetic materials.

\section{Genetic parameters}

The means from ANOVA were used to calculate genetic parameters such as genotypic coefficient of variation $(\mathrm{GCV})$, phenotypic coefficient of variation (PCV), environmental coefficient of variation (ECV), genotypic variance, phenotypic variance, environmental variances, coefficient of variation $(\mathrm{CV})$ and genetic advance to show variability in maize genotypes. The phenotypic variation for each trait was separated into genetic and environmental (non-genetic) factors and estimated according to Burton (1952) and Sharma (1988), as follows:

$$
\begin{array}{ll}
\sigma_{\mathrm{e}}^{2}=\mathrm{MSe} & \text { equation 1 } \\
\sigma_{\mathrm{g}}^{2}=(\mathrm{MSg}-\mathrm{MSe}) / \mathrm{r} & \text { equation 2 } \\
\sigma_{\mathrm{p}}^{2}=\sigma_{\mathrm{g}}^{2}+\sigma_{\mathrm{e}}^{2} & \text { equation 3 } \\
\sigma_{\mathrm{e}}^{2} \%=\left(\sigma_{\mathrm{e}}^{2} / \sigma_{\mathrm{p}}^{2}\right) * 100 & \text { equation 4 }
\end{array}
$$

Where: $\sigma_{\mathrm{p}}^{2}, \sigma_{\mathrm{g}}^{2}$ and $\sigma_{\mathrm{e}}^{2}$ are phenotypic variance, genotypic variance and environmental variance, respectively, and $\mathrm{MS}_{\mathrm{g}}, \mathrm{MS}_{\mathrm{e}}$ and $\mathrm{r}$ are the mean squares of genotypes, mean squares of error and number of blocks, respectively. 


$$
\begin{aligned}
\% \mathrm{CV}=\frac{\sqrt{\mathrm{MS}}}{\overline{\mathrm{x}}} \times 100 & \text { equation } 5 \\
\mathrm{PCV}=\frac{\sqrt{\sigma_{\mathrm{p}}^{2}}}{\overline{\mathrm{X}}} \times 100 & \text { equation } 6 \\
\mathrm{GCV}=\frac{\sqrt{\sigma_{\mathrm{g}}^{2}}}{\overline{\mathrm{X}}} \times 100 & \text { equation } 7 \\
\mathrm{ECV}=\frac{\sqrt{\sigma_{\mathrm{e}}^{2}}}{\overline{\mathrm{x}}} \times 100 & \text { equation } 8
\end{aligned}
$$

Where: $\bar{x}$ is the grand mean for each trait measured.

Broad sense heritability $\left(\mathrm{h}_{\mathrm{bs}}^{2}\right)$ expressed as the percentage of the ratio of the genotypic variance $\left(\sigma_{\mathrm{g}}^{2}\right)$ to the phenotypic variance $\left(\sigma_{\mathrm{p}}^{2}\right)$ was estimated as described by Burton (1952).

Genetic advance (GA) was estimated by the methods of Fehr (1987) as:

$\mathrm{GA}=\mathrm{K}\left(\mathrm{S}_{\mathrm{p}}\right) \mathrm{h}_{\mathrm{bs}}^{2}$

equation 9

Where: $K$ is a constant $(2.06)$ at $5 \%$ selection pressure, $S_{\mathrm{p}}$ is the phenotypic standard deviation $\left(\sqrt{\sigma_{\mathrm{p}}^{2}}\right)$, $\mathrm{h}^{2}$ bs is the heritability ratio.

GA was also calculated as percentage of mean.

\section{Results and Discussion}

\section{Genetic variability}

Variation among a given plant population is highly indispensable in order to achieve success in any crop improvement programme. Table 2 showed the estimates of the variances and genetic parameters of the 10 maize genetic materials evaluated in 2015 and 2016 planting seasons for various quantitative traits. Variability of a trait is necessary for its inclusion in crop improvement programme (Chukwudi and Agbo, 2016; Ene et al., 2016). Percentage coefficient of variation (CV\%) provides comparative assessment of the amount of variability between crop traits (Ene et al., 2016). In 2015, the highest coefficient of variation was recorded in leaf dry matter, followed by tasselling silking interval and grain yield hectare ${ }^{-1}$, while tasselling silking interval took the lead in the 2016 evaluation, followed by grain yield hectare ${ }^{-1}$ and leaf dry matter. Grain filling period showed low coefficient of variation in both years of study and was followed by cob dry weight and 100-seed weight in 2015. The implication of these low coefficients of variation is the lesser ability of the affected traits to be advanced in selection due to low variation in the traits among the maize population.

The genotype evaluation in 2015 showed phenotypic variance in the range of 1.83 for grain yield to 5,393 for number of grains $\mathrm{cob}^{-1}$. The highest value obtained from number of grains per cob was followed by cob dry weight, leaf dry matter and plant height. Phenotypic variance is influenced by genotypic variance and environmental variance (Andrade, 2019). Among the four traits with high phenotypic variances, number of grains per cob and leaf dry matter had higher genotypic variance than environmental variance, while cob dry weight and plant height had higher environmental variance than genotypic variance. The contribution (\%) of the environmental variance to the phenotypic variance was highest for the number of leaves (98.7\%), followed by cob dry weight (85.5\%), plant height (82.2\%) and 100-seed weight (77.4\%). Environmental variance contributions on the other traits were below 50\%. In 2016 evaluation, the patterns of environmental and genotypic contributions to the phenotypic variance were similar to those observed in 2015 evaluation. The contribution of the environmental variance on number of leaves, cob dry weight, plant height and 100-seed weight were $99.5 \%, 96.2 \%, 88.6 \%$ and $67.1 \%$, respectively, with the other traits having $<50 \%$ contribution from the environment. These high environmental contributions may account for the non-significant difference 
observed in the mean square of the genotypes as the four traits with above $50 \%$ environmental contribution were not significant in both evaluations. Table 2 revealed that as environmental contribution to the phenotypic variance increased, the broad sense heritability decreased. In both evaluations, the traits with the highest environmental contribution had the least broad sense heritability vis-a-vis the traits with the lowest environmental contribution. Heritability in broad sense signifies the genetic variability among genitors, indicating their propensity to respond to selection pressure (Milatovic et al., 2010; Rahman et al., 2017). High heritability shows a minimal environmental effect on the observed variation (Bhiusal et al., 2017).

High genetic advance was observed for number of grains per cob, leaf dry matter and number of days to physiological maturity, while number of leaves per plant and 100-seed weight showed low genetic advance in both evaluations. Moderate to high heritability and genetic advance estimates for a given trait signify additive genes as being responsible for its performance, hence, distinguishes the trait for direct selection (Ndukauba et al., 2015; Bhiusal et al., 2017). Medium to high heritability and genetic advance estimates recorded for number of grains per cob, leaf dry matter and number of days to physiological maturity in both evaluations give them an edge for selection in maize improvement programme in the derived savannah agro-ecology.

Table 2. Mean square and genetic parameters for 12 quantitative traits in maize genotypes

\begin{tabular}{|c|c|c|c|c|c|c|c|c|c|c|c|}
\hline Traits & Mean & $\mathrm{Vp}$ & $\mathrm{Vg}$ & $\mathrm{Ve}$ & PCV & GCV & $\mathrm{ECV}$ & $\% \mathrm{CV}$ & $\mathrm{H}^{2}{ }_{b s}(\%)$ & GA & MSG \\
\hline \multicolumn{12}{|c|}{2015} \\
\hline $\mathrm{PH}$ & 90.43 & 725.83 & 129.33 & 596.50 & 29.79 & 12.58 & 27.01 & 34.70 & 17.82 & 9.89 & $984.50^{\text {ns }}$ \\
\hline NOL & 9.01 & 3.71 & 0.05 & 3.66 & 21.38 & 2.48 & 21.23 & 21.64 & 1.35 & 0.05 & $3.80^{\mathrm{ns}}$ \\
\hline LDM & 52.35 & 746.77 & 508.87 & 237.90 & 52.20 & 43.09 & 29.46 & 80.24 & 68.14 & 38.36 & $1764.50^{* *}$ \\
\hline $\mathrm{D} 50 \mathrm{~T}$ & 65.73 & 59.13 & 46.76 & 12.37 & 11.70 & 10.40 & 5.35 & 18.80 & 79.08 & 12.53 & $152.65^{* *}$ \\
\hline D50S & 70.17 & 93.56 & 76.67 & 16.89 & 13.78 & 12.48 & 5.86 & 22.39 & 81.95 & 16.33 & $246.91^{* *}$ \\
\hline TSI & 4.43 & 5.15 & 3.43 & 1.72 & 51.23 & 41.81 & 29.60 & 78.21 & 66.60 & 3.11 & $12.00^{* *}$ \\
\hline GFP & 40.17 & 13.71 & 7.12 & 6.59 & 9.22 & 6.64 & 6.39 & 13.16 & 51.93 & 3.96 & $27.94^{* *}$ \\
\hline PMT & 110.53 & 144.35 & 114.31 & 30.04 & 10.87 & 9.67 & 4.96 & 17.47 & 79.19 & 19.60 & $372.98^{* *}$ \\
\hline NGC & 277.52 & 5393 & 2757 & 2636 & 26.46 & 18.92 & 18.50 & 37.63 & 51.12 & 77.33 & $10907.00^{* *}$ \\
\hline 100SW & 21.85 & 13.34 & 3.02 & 10.32 & 16.72 & 7.95 & 14.70 & 20.14 & 22.64 & 1.70 & $19.37^{\mathrm{ns}}$ \\
\hline CDW & 167.4 & 2328 & 338 & 1990 & 28.82 & 10.98 & 26.65 & 32.74 & 14.52 & 14.43 & $3004.00^{\mathrm{ns}}$ \\
\hline GY & 2.92 & 1.83 & 1.60 & 0.23 & 46.33 & 43.32 & 16.42 & 76.79 & 87.43 & 2.44 & $5.03^{* *}$ \\
\hline \multicolumn{12}{|c|}{2016} \\
\hline $\mathrm{PH}$ & 86.18 & 714.60 & 81.70 & 632.90 & 31.02 & 10.49 & 29.19 & 34.38 & 11.43 & 6.29 & $878.00^{\text {ns }}$ \\
\hline NoL & 8.63 & 3.80 & 0.02 & 3.78 & 22.59 & 1.64 & 22.53 & 22.65 & 0.53 & 0.02 & $3.42^{\text {ns }}$ \\
\hline LDM & 55.93 & 457.50 & 308 & 149.50 & 38.24 & 31.38 & 21.86 & 58.58 & 67.32 & 29.66 & $1073.50^{* *}$ \\
\hline $\mathrm{D} 50 \mathrm{~T}$ & 65.97 & 79.73 & 75.97 & 3.76 & 13.54 & 13.21 & 2.94 & 23.07 & 95.28 & 17.53 & $231.66^{* *}$ \\
\hline D50S & 70.17 & 120.74 & 112.71 & 8.03 & 15.66 & 15.13 & 4.04 & 26.51 & 93.35 & 21.13 & $346.17^{* *}$ \\
\hline TSI & 4.20 & 5.05 & 3.93 & 1.12 & 53.51 & 47.20 & 25.20 & 85.53 & 77.82 & 3.60 & $12.90^{* *}$ \\
\hline GFP & 40.37 & 15.51 & 9.11 & 6.40 & 9.76 & 7.48 & 6.27 & 14.39 & 58.74 & 4.77 & $33.74^{* *}$ \\
\hline PMT & 110.67 & 177.02 & 154.86 & 22.16 & 12.02 & 11.24 & 4.25 & 19.94 & 87.48 & 23.98 & $486.74^{* *}$ \\
\hline NGC & 278.38 & 6927.67 & 5404.67 & 1523 & 29.90 & 26.41 & 14.02 & 47.84 & 78.02 & 133.77 & $17737.00^{* *}$ \\
\hline $100 S W$ & 22.13 & 0.85 & 0.28 & 0.57 & 4.17 & 2.39 & 3.41 & 5.34 & 32.94 & 0.63 & $0.23^{\mathrm{ns}}$ \\
\hline $\mathrm{CDW}$ & 212.57 & 24.61 & 0.93 & 23.68 & 2.33 & 0.45 & 2.29 & 2.42 & 3.78 & 0.39 & $26.46^{\mathrm{ns}}$ \\
\hline GY & 2.87 & 1.28 & 0.79 & 0.49 & 39.42 & 30.97 & 24.39 & 58.99 & 61.72 & 1.44 & $2.87^{* *}$ \\
\hline
\end{tabular}

$\mathrm{PH}=$ Plant height $(\mathrm{cm}) @ 8$ week after planting, NOL = number of leaves @ 8 week after planting; D50T = Days to $50 \%$ tassels appearance, D50S = Days to 50\% silk appearance, LDM = Leaf dry matter (g), TSI = Tassel-silk interval, GFP = Grain filling period, PMT $=$ Day to physiological maturity, NGC $=$ Number of grains per cob, 100SW $=100$ Seed weight (g), CDW = Cob dry weight $(\mathrm{g}), \mathrm{GY}=$ Grain yield per hectare (ton). $\mathrm{V}_{\mathrm{p}}=$ Phenotypic variance, $\mathrm{V}_{\mathrm{g}}=$ Genotypic variance, $V_{e}=$ Environmental variance, $G C V=$ Genotypic coefficient of variation, $P C V=$ Phenotypic coefficient of variation, ECV = Environmental coefficient of variation, \%CV = Percentage coefficient of variation, GA $=$ Genetic advance, $\mathrm{H}^{2} \mathrm{bs}=$ Broad-sense heritability, $\mathrm{MSG}=$ Mean square of genotypes, ${ }^{* * *}=$ very highly significant, ${ }^{* *}$ $=$ highly significant ${ }^{*}=$ significant and $n s=$ non-significant 


\section{Principal component analysis}

Principal component analysis is used in evaluating the patterns of variation in germplasm (Chukwudi and Agbo, 2016). The Principal component analysis results indicated that the first two axes explained $91.8 \%$ and $93.3 \%$ of the total variation in 2015 and 2016, respectively (Table 3). In 2015, the principal component axes 1 (PC1) explained $65.1 \%$ of the total variation, while PC2 accounted for $26.62 \%$ of the variation unaccounted for by PC1. Number of grains $\mathrm{cob}^{-1}$, cob dry weight and plant height influenced the first principal component axis, while cob dry weight, leaf dry matter and number of days to physiological maturity affected the second principal component axis. In 2016, number of grains $\operatorname{cob}^{-1}$, plant height and number of days to physiological maturity influenced the first principal component axis which accounted for $85.2 \%$ of the total variation. In the hereby study, number of grains $\operatorname{cob}^{-1}$ was implicated as the most discriminating trait, portraying greater variation among maize lines in both years. It was followed by plant height and number of days to physiological maturity in both years. Cob dry weight was inconsistent in influencing the variation in the maize population in both years. Number of grains $\mathrm{cob}^{-1}$, plant height and number of days to physiological maturity were consistent in explaining the variations observed in the maize population. These traits had been flagged by Azad et al. (2012) and Hartings et al. (2008) as being important in explaining variations in maize germplasm. Therefore, they should be considered in maize improvement program in derived savannah agroecology. Principal component analysis has been successfully used for explaining observed variations in germplasms of Vigna unguiculata (Ansah et al., 2016), Telfairia occidentalis (Chukwdi and Agbo, 2016), Cucumis sativus L. (Ene et al., 2016), pointed gourd (Verma et al., 2017).

Table 3. Percentage variation and latent loading of the principal component axes of maize genotypes

\begin{tabular}{|c|c|c|c|c|}
\hline \multirow{2}{*}{ Traits } & \multicolumn{2}{|c|}{2015} & \multicolumn{2}{|c|}{2016} \\
\hline & $\mathrm{PC1}$ & PC2 & $\mathrm{PC1}$ & PC2 \\
\hline Plant height $(\mathrm{cm})$ & 0.20636 & -0.01028 & 0.11456 & -0.85002 \\
\hline No of leaves & 0.01385 & -0.00114 & 0.00721 & -0.05208 \\
\hline Leaf dry matter $(\mathrm{g})$ & 0.02242 & 0.49433 & -0.02352 & 0.44150 \\
\hline Days to $50 \%$ tassel appearance & -0.05761 & 0.09034 & -0.07971 & 0.12646 \\
\hline Days to $50 \%$ silk appearance & -0.07482 & 0.11436 & -0.10248 & 0.13726 \\
\hline Tassel-silk interval & -0.01721 & 0.02403 & -0.02277 & 0.01080 \\
\hline Grain filling period & -0.00586 & 0.03548 & -0.01646 & 0.01114 \\
\hline Days to physiological maturity & -0.08071 & 0.14834 & -0.11964 & 0.14442 \\
\hline No of grains $\mathrm{cob}^{-1}$ & 0.92084 & -0.24727 & 0.97683 & 0.15346 \\
\hline 100-Seed weight $(\mathrm{g})$ & 0.02741 & 0.02769 & -0.00095 & -0.00345 \\
\hline Cob dry weight (g) & 0.30349 & 0.80531 & -0.00037 & 0.01631 \\
\hline Grain yield ha ${ }^{-1}$ (tons) & 0.01219 & -0.00477 & 0.01068 & 0.00837 \\
\hline Percentage variation & 65.13 & 26.62 & 85.17 & 8.10 \\
\hline Cumulative variation & 65.13 & 91.75 & 85.17 & 93.27 \\
\hline
\end{tabular}

Plant height and no. of leaves were recorded at 8 weeks after planting, PC1 and PC2 = First and second principal component axes

\section{Cluster analysis}

The dendrogram showed that at $80 \%$ dissimilarity point, the maize varieties studied were grouped into three clusters (A, B and C) in both years. In 2015, cluster A consists of an outlier 'Oka Awaka', while cluster B is made up of five varieties namely 'DT-SR-WCQ', 'TZE COMP.3C2DT', 'DT-SYN-7-WF2', 'DT-SYN-11YF2' and 'Oba Super 2' (Figure 2). The remaining four varieties ('2008DTM A-YSTR', 'IW DC3 SYN/DTSYN-1-W', 'IWDC2SYN-F2' and 'EVDT-Y2000STRCO') fell into cluster C. There was similarity in the clustering for both years except for 'DT-SYN-11-YF2' inbred line, that moved from cluster B in 2015 to cluster $\mathrm{C}$ in 2016 (Figures 2 and 3). 
The cluster means are presented in Table 4. In 2015, 'Oka Awaka' gave the highest number of days to $50 \%$ tassel and silk appearance, tassel-silk interval, grain filling interval, physiological maturity and cob dry weight compared to clusters B and C. Its 100-seed weight was above the population mean, while its plant height, number of leaves, grains $\mathrm{cob}^{-1}$ and yield per hectare were the lowest and below the population mean. Cluster $\mathrm{B}$ gave the highest mean for number of leaves, grains $\mathrm{cob}^{-1}, 100$-seed weight and grain yield per hectare. Its plant height was above the population mean, while the floral attributes were below the population mean and was least in number of days to $50 \%$ tassel appearance, silk appearance and tassel-silk interval. The highest plant height mean was obtained in cluster $C$ with number of leaves that was above the population mean. The floral attributes of cluster $\mathrm{C}$ are similar to cluster $\mathrm{B}$ as they were below the population mean. However, cluster C gave the lowest means for 100-seed weight and cob dry weight. In 2016, the cluster means followed the same trend as in 2015 except that 'Oka Awaka' produced the highest 100-seed weight. Also, the number of grains $\mathrm{cob}^{-1}$ in cluster $\mathrm{C}$ was above the population mean.

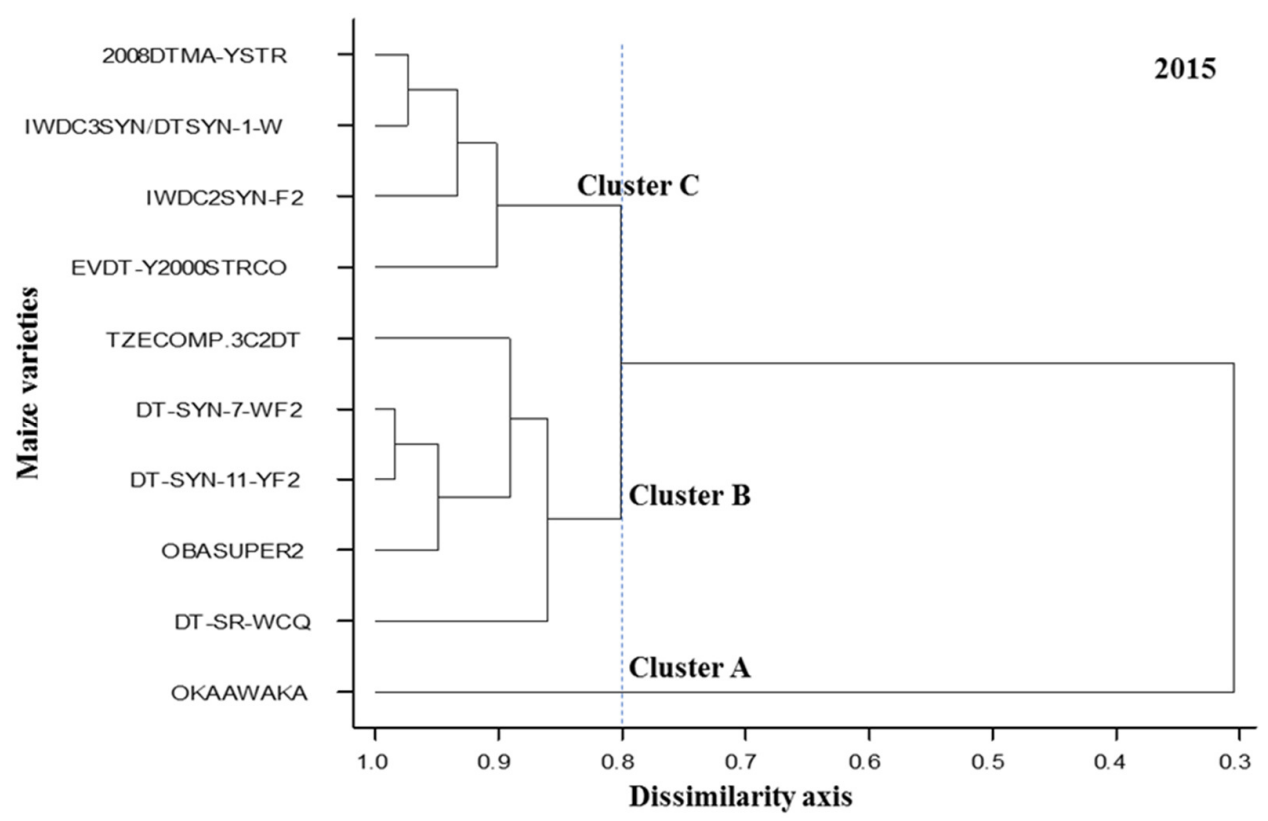

Figure 2. Dendrogram of the 10 genotypes of maize following Ward's method 
Inyang P et al. (2021). Not Sci Biol 13(1):10691

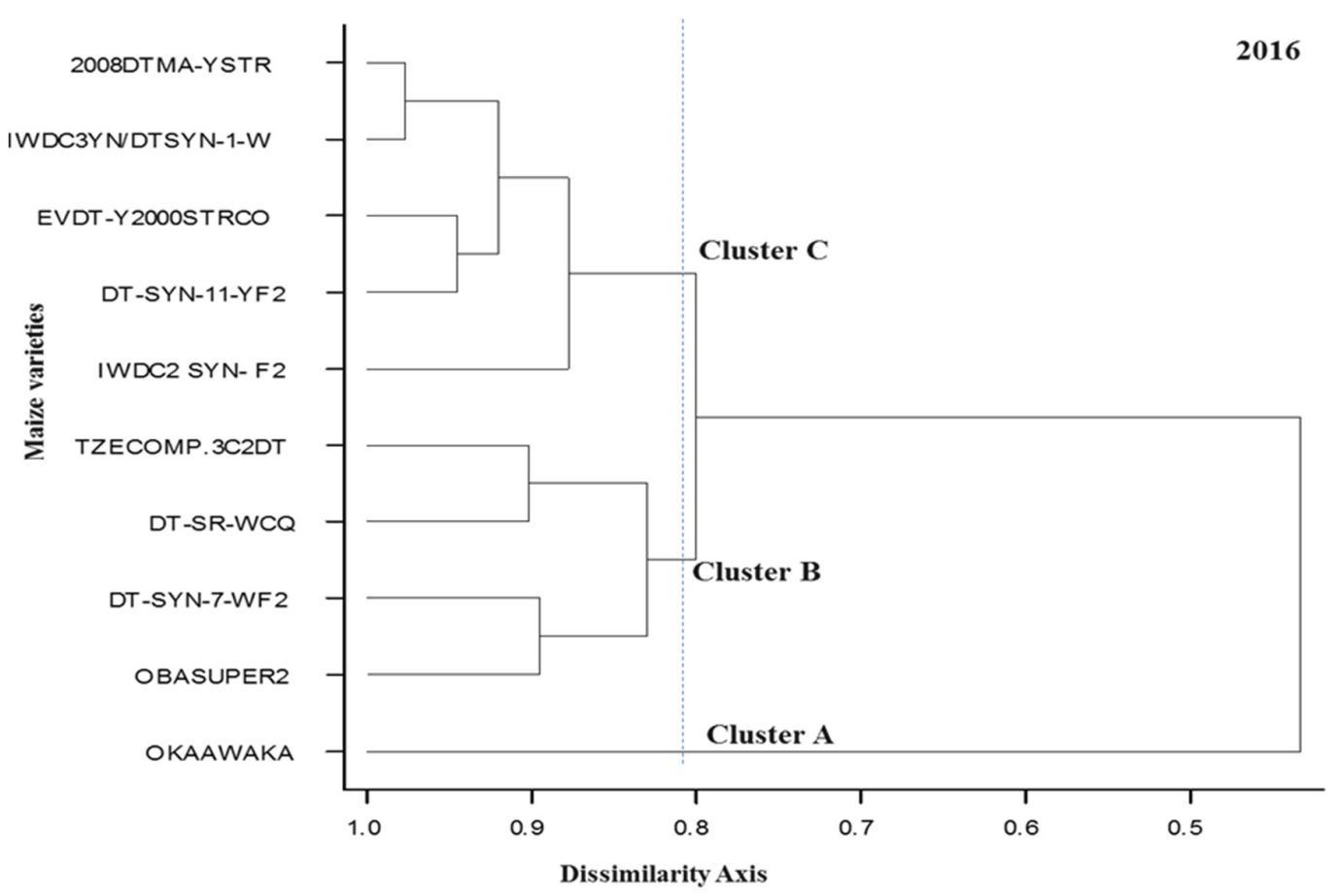

Figure 3. Dendrogram of the 10 genotypes of maize following Ward's method 
Table 4. Cluster means of 12 traits used in the classification of maize genotypes

\begin{tabular}{|c|c|c|c|c|}
\hline Traits & Cluster A & Cluster B & Cluster C & $\begin{array}{c}\text { Population } \\
\text { mean }\end{array}$ \\
\hline \multicolumn{5}{|c|}{2015} \\
\hline Plant height $(\mathrm{cm})$ & 58.4 & 93.9 & 94.1 & 82.1 \\
\hline No of leaves & 6.9 & 9.5 & 9.0 & 8.5 \\
\hline Leaf dry matter $(\mathrm{g})$ & 115.6 & 52.6 & 36.2 & 68.2 \\
\hline Days to $50 \%$ tassel appearance & 83.7 & 63.7 & 63.8 & 70.4 \\
\hline Days to $50 \%$ silk appearance & 93.3 & 67.2 & 68.1 & 76.2 \\
\hline Tassel-silk interval & 9.7 & 3.5 & 4.3 & 5.8 \\
\hline Grain filling period & 45.3 & 40.9 & 38.0 & 41.4 \\
\hline Days to physiological maturity & 138.7 & 108.2 & 106.4 & 117.8 \\
\hline No of grains cob-1 & 184.1 & 326.2 & 240.1 & 250.1 \\
\hline 100-Seed weight $(\mathrm{g})$ & 22.1 & 23.6 & 19.6 & 21.8 \\
\hline Cob dry weight (g) & 233.3 & 177.7 & 138.1 & 183.0 \\
\hline Grain yield ha-1 (tons) & 1.5 & 3.9 & 2.0 & 2.5 \\
\hline \multicolumn{5}{|c|}{2016} \\
\hline Plant height $(\mathrm{cm})$ & 57.0 & 88.8 & 89.9 & 78.6 \\
\hline No of leaves & 6.8 & 8.7 & 9.0 & 8.1 \\
\hline Leaf Dry Matter $(\mathrm{g})$ & 100.2 & 59.8 & 44.0 & 68.0 \\
\hline Days to $50 \%$ tassel appearance & 88.7 & 63.3 & 63.5 & 71.8 \\
\hline Days to $50 \%$ silk appearance & 98.0 & 66.3 & 67.7 & 77.3 \\
\hline Tassel-silk interval & 9.3 & 3.0 & 4.1 & 5.5 \\
\hline Grain filling period & 45.0 & 40.5 & 39.3 & 41.6 \\
\hline Days to physiological maturity & 143.0 & 106.8 & 107.3 & 119.0 \\
\hline No of grains $\mathrm{cob}^{-1}$ & 128.8 & 341.0 & 258.2 & 242.7 \\
\hline 100-Seed weight $(\mathrm{g})$ & 22.8 & 22.3 & 22.2 & 22.4 \\
\hline Cob dry weight (g) & 213.5 & 212.3 & 212.6 & 212.8 \\
\hline Grain yield ha $^{-1}$ (tons) & 1.7 & 3.7 & 2.5 & 2.6 \\
\hline
\end{tabular}

Plant height and no. of leaves were recorded at 8 weeks after planting

The cluster means revealed that the varieties were grouped based on their growth, floral and yield performances. 'Oka Awaka' was poor in the measured growth and floral traits. It had prolonged vegetative phase compared to clusters B and C. The growth and floral traits of clusters B and C were similar, but the yield traits differentiated the two clusters. Cluster B showed superior yield performance over cluster $\mathrm{C}$. The grouping of the varieties aligned to their initial growth duration (Table 1). 'Oka Awaka' previously unclassified based on growth duration took 139 days to reach physiological maturity. The varieties in cluster B are late maturing varieties except 'TZE COMP.3C2DT' that was classified as early maturing. Cluster C contained the early and intermediate maturing varieties. The grain colour was randomly distributed among the clusters. The superior yield performance of varieties in cluster B over 'Oka Awaka' and cluster C implied that they can be used for maize improvement program or direct introduction in the derived savannah agro-ecology. Cluster analysis has proved to be an effective method in grouping accessions (Shukla et al., 2010; Chukwudi and Agbo, 2016) which is important in maintaining their biodiversity and utilization in crop improvement program (Chukwudi and Agbo, 2016). Cluster analysis had been used in maize improvement studies in different parts of the world (Bhiusal et al., 2017; Hartings et al., 2008; Liu et al., 2006; Rahman et al., 2017; Subramanian and Subbaraman, 2010). 


\section{Conclusions}

The maize genotypes evaluated in the current study expressed their genetic diversity within the growth, floral and yield traits investigated. Environmental contribution to the phenotypic variance was the highest for the number of leaves, followed by cob dry weight, plant height and 100-seed weight in both years. Moderate to high heritability and genetic advance estimates were observed for the number of days to physiological maturity, leaf dry matter and number of grains per cob in both years. However, the principal component analysis indicated that the number of grains per cob, plant height and number of days to physiological maturity were consistent in explaining the variations observed in the maize population. Growth, floral and yield traits were used in grouping the varieties into three clusters. Cluster B gave the highest mean for number of leaves, number of grains per cob, 100-seed weight and grain yield per hectare, with plant height that was above the population mean, while its floral attributes were below the population mean. 'Oba Super 2', a commercial hybrid and three DT genotypes namely 'DT-SR-WCQ', 'TZE COMP.3C2DT' and 'DT-SYN-7-WF2' were consistently grouped into cluster B in both years. These three DT maize genotypes should be used in maize breeding programs or directly introduced to farmers in the derived savannah agro-ecology.

\section{Authors' Contributions}

PI: Conceptualization, investigation and methodology; COE: Writing - original draft; AE: Data curation; UPC: Writing - review and editing: UNI: Supervision; Visualization.

All authors read and approved the final manuscript.

\section{Acknowledgements}

The authors are grateful to IITA, Ibadan, Nigeria for providing them with the eight-drought tolerant maize shortly after their release in 2015 .

\section{Conflict of Interests}

The authors declare that there are no conflicts of interest related to this article.

\section{References}

Andrade JAC (2019). Genetic variability and breeding potential of Flintisa composite of maize in two levels of technology. Crop Breeding and Applied Biotechnology 19(2):145-152. https://doi.org/10.1590/1984-70332019v19n2a21

Ansah SG, Adudapaah H, Kumaga F, Gracen V, Nartey FK (2016). Evaluation of cowpea (Vigna unguiculata [L.] Walp) genotypes for phosphorus use efficiency. Acta Horticulturae 1127:373-380. https://doi.org/10.17660/ActaHortic.2016.1127.58

Azad MAK, Biswas BK, Alam N, Alam SKS (2012). Genetic diversity in maize (Zea mays L.) inbred lines. The Agriculturists 10(1):64-70. https://doi.org/10.3329/agric.v10i1.11066

Bhiusal TN, Lal GM, Marker S, Synrem GJ (2017). Genetic variability and traits association in maize (Zea mays L.) genotypes. Annals of Plant and Soil Research 19(1):59-65.

Brandt M, Wigneron JP, Chave J, Tagesson T, Penuelas J, Ciais P, ... Fensholt R (2018). Satellite passive microwaves reveal recent climate-induced carbon losses in African drylands. Nature Ecology \& Evolution 2(5):827. https://doi.org/10.1038/s41559-018-0530-6 
Burton GW (1952). Qualitative inheritance in grasses. Proceedings of the $6^{\text {th }}$ International Grassland Congress, pp 277283.

Chukwudi UP, Agbo CU (2016). Characterization and preliminary evaluation of local germplasm of Telfairia occidentalis Hook F. accessions in Enugu, Nigeria. Agro-Science 15(2):15-22. https://doi.org/10.4314/as.v15i2.3

CIMMYT (2015). A quarterly bulletin of the drought tolerant maize for Africa Project 4(4). Retrieved 2018 March from https://repository.cimmyt.org/

Ene CO, Ogbonna PE, Agbo CU, Chukwudi UP (2016). Studies of phenotypic and genotypic variation in sixteen cucumber genotypes. Chilean Journal of Agricultural Research 76(3):307-313. https://doi.org/10.4067/S071858392016000300007

Fehr WR (1987). Principles of cultivar development: Crop Species, First Ed. Macmillan; New York.

Fisher M, Abate T, Lunduka RW, Asnake W, Alemayehu Y, Madulu RB (2015). Drought tolerant maize for farmer adaptation to drought in sub-Saharan Africa: Determinants of adoption in eastern and southern Africa. Climatic Change 133:283-299. https://doi.org/10.1007/s10584-015-1459-2

Hartings H, Berardo N, Mazzinelli GF, Valoti P, Verderio A, Motto M (2008). Assessment of genetic diversity and relationships among maize (Zea mays L.) Italian landraces by morphological traits and AFLP profiling. Theoretical and Applied Genetics 117(6):831-842. https://doi.org/10.1007/s00122-008-0823-2

IWMI (2019). International Water Management Institute (IWMI)-World Water Day. Voicing water visions in river basins across the developing world. Retrieved 2019 March 22 from www.iwmi.cgiar.org/news/campaigns/worldwater-day/2019-22/

Kansiime MK, Mastenbroek A (2016). Enhancing resilience of farmer seed system to climate-induced stresses: Insights from a case study in West Nile region Uganda. Journal of Rural Studies 47:220-230. https://doi.org/10.1016/j.jrurstud.2016.08.004

Liu YA, Hou JH, Gao ZJ, Zhou W (2006). Principal component analysis and cluster analysis of introduced maize varieties. Journal of Maize Sciences 14(2):16-18.

Milatovic D, Nikolic D, Durovic D (2010). Variability, heritability and correlation of some factors affecting productivity in peach. Horticultural Science 37(3):79-87. https://doi.org/10.17221/63/2009-HORTSCI

Ndukauba J, Nwofia GE, Okocha PI, Ene-Obong EE (2015). Variability in egusi-melon genotypes (Citrullus lanatus [Thumb] Matsum and Nakai) in derived savannah environment in South-Eastern Nigeria. International Journal of Plant Research 5(1):19-26. https://doi.org/10.5923/j.plant.20150501.04

New Partnership for Africa's Development (NEPAD) (2014). Agriculture in Africa. Transformation and Outlook. Retrieved 2019 February 15 from www.nepad.org/system/files/Agriculture\%20in\%20Africa.pdf

OECD/FAO (2016). Agriculture in Sub-Saharan Africa: Prospects and challenges for the next decade. In: OECD-FAO Agricultural Outlook 2016-2025, OECD Publishing, Paris.

Rahman M, Hoque A, Hossain Md. A, Al Bari Md A (2017). Variability and traits association analyses in maize (Zea mays L.) genotypes. The Agriculturists 15(2):101-114.

Ramirez-Cabral NYZ, Kumar L, Shabani F (2017). Global alterations in areas of suitability for maize production from climate change and using a mechanistic species distribution model (CLIMEX). Scientific Reports 7:5910. https://doi.org/10.1038/s41598-017-05804-0

Rosegrant MW, Msangi S (2011). Feeding the future's changing diets: Implications for agricultural markets, nutrition, and policy. In: International Food Policy Research Institute (IFPRI) 2020 Conference: Leveraging Agriculture for Improving Nutrition and Health. New Delhi, pp 12.

Sharma JR (1988). Statistical and biometrical techniques in plant breeding. First ed., New Age International Limited Publishers; New Delhi.

Shukla S, Bhargava A, Chatterjee A, Pandey AC, Mishra BK (2010). Diversity in phenotypic and nutritional traits in vegetable amaranth (Amaranthus tricolor L.), a nutritionally under-utilized crop. Journal of the Science of Food and Agriculture90(1):139-144. https://doi.org/10.1002/jsfa.3797

Soil Survey Staff (2003). Keys to soil taxonomy. 9th Ed. USDA, United States Department of Agriculture: Natural Resources Conservation Service.

Subramanian A, Subbaraman N (2010). Hierarchical cluster analysis of genetic diversity in maize germplasm. Electronic Journal of Plant Breeding 1(4):431-436.

Uba CU, Agbo CU, Chukwudi UP, Efusie AA, Muojiama SO (2018). Field evaluation of yield and yield component traits of breeding lines of maize over two seasons in derived savannah agro-ecology. Notulae Scientia Biologicae 10:567-574. https://doi.org/10.25835/nsb10410329 
Ullah MZ, Hassan MJ, Chowdhury AZMKA, Saki AI, Rahman AHMA (2012). Genetic variability and correlation in exotic cucumber (Cucumis sativus L.) varieties. Bangladesh Journal of Plant Breeding and Genetics 25(1):17-23. https://doi.org/10.3329/bjpbg.v25i1.17008

Verma P, Maurya SK, Yadav H, Panchbhaiya A (2017). Determination of genetic divergence in pointed gourd by principal component and non-hierarchical Euclidean cluster analysis. Journal of Applied and Natural Science 9(4):24212426. https://doi.org/10.31018/jans.v9i4.1548
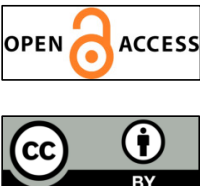

The journal offers free, immediate, and unrestricted access to peer-reviewed research and scholarly work. Users are allowed to read, download, copy, distribute, print, search, or link to the full texts of the articles, or use them for any other lawful purpose, without asking prior permission from the publisher or the author.

License - Articles published in Notulae Scientia Biologicae are Open-Access, distributed under the terms and conditions of the Creative Commons Attribution (CC BY 4.0) License.

(c) Articles by the authors; SHST, Cluj-Napoca, Romania. The journal allows the author(s) to hold the copyright/to retain publishing rights without restriction. 